\title{
Medieval Irish medical verse in the nineteenth century: some evidence from material culture
}

\author{
DEBORAH HAYDEN* \\ Ollscoil Mhá Nuad/Maynooth University
}

\begin{abstract}
A B S T R A C T. This article presents an edition and translation of an Irish didactic poem found in a large compilation of remedies, charms and prayers that was written in the early sixteenth century by the Roscommon medical scribe Conla Mac an Leagha. The contents of this poem, and of the treatise in which it occurs more generally, are of inherent interest for our understanding of the history of medical learning in medieval Ireland. However, the poem is also of particular significance due to the fact that its penultimate stanza, which invokes the authority of one 'Colmán mac Oililla', is attested in two much later sources that provide insight into the transmission and reception of medieval Irish medical texts in the early nineteenth century, as well as into the relationship between manuscript, print and material culture during that period. The two sources in question, one of which is a previously unprovenanced signboard now kept in the Wellcome Collection in London, can both be connected with the work of the Munster 'herb doctor' Michael Casey (1752?-1830/31), who in 1825 advertised the publication of a new herbal containing cures derived from much earlier Irish-language medical manuscripts.
\end{abstract}

$\mathrm{T}$ he transmission of knowledge in verse form has a long history in Ireland and encompasses a wide variety of literary genres. Not all of these genres have received equal attention in modern scholarship, however; it has recently been observed, for example, that much scholarly discussion of medieval Irish poetry has tended to focus on a small corpus of oft-anthologised compositions that 'most closely conform to modern expectations of poetry, that is, lyric poetry, narrative verse, occasional verse and nature poetry'. This emphasis has, in many respects, obscured the bulk of the surviving evidence for the literary form in question, which also includes compositions pertaining to subjects of a far more technical nature such as genealogy, historiography, legal principles, grammatical rules or cosmology - material that was clearly cast in a metrical mould at least partly, if not entirely, for mnemonic or didactic purposes. ${ }^{2}$

* Roinn na Sean-Ghaeilge, Ollscoil Mhá Nuad,Deborah.Hayden@mu.ie.

${ }^{1}$ Elizabeth Boyle, 'The forms and functions of medieval Irish poetry and the limitations of modern aesthetics' in Tom Birkett and Kirsty March Lyons (eds), Translating early medieval poetry for the twenty-first century: transformation, reception, interpretation (Woodbridge, 2017), pp 92-108, at p. 93.

${ }^{2}$ For a general discussion of the scope of medieval Irish verse, see Liam Breatnach, 'Poets and Poetry' in Kim McCone and Katharine Simms (eds), Progress in medieval Irish studies (Maynooth, 1996), pp 65-77. 
One particular category of Irish versified technical literature that has received hardly any consideration at all is that pertaining to medical learning. The scarcity of commentary on this topic, or of editions of Irish didactic medical poems, is not surprising given the relative dearth of attention that has been paid by modern scholars to the extant corpus of Irish medical manuscripts as a whole, which comprises well over a hundred codices written between the fourteenth and seventeenth centuries. ${ }^{3}$ For a long time, the only published didactic medical poems in Irish consisted of two short compositions edited in the early twentieth century by Robin Flower from a manuscript that is otherwise mostly non-medical in nature; both of the poems in question are probably versified translations of prose material from a source in either Latin or another vernacular. ${ }^{4}$

More recent research has brought to light a total of five further Irish medical poems that are found in a remedy book compiled in the early sixteenth century, where they constitute only a small proportion of a much larger collection of technical verse encompassing some forty-three separate didactic poems that range in length from a single stanza to twenty-three quatrains. ${ }^{5}$ This treatise, now preserved as part of two distinct, composite manuscripts in the Royal Irish Academy library in Dublin, consists of over 920 herbal remedies, charms and prayers for ailments affecting all parts of the human body, broadly arranged in the head-to-toe order typical of many premodern medical texts. ${ }^{6}$ The principal scribe of the collection was Conla Mac an Leagha ( $f$. 1496-1512), who is known from several manuscript

${ }^{3}$ For a useful overview of the extant Irish medical manuscripts, see Aoibheann Nic Dhonnchadha, 'Medical writing in Irish' in Irish Journal of Medical Science, clxix, no. 3 (2000), pp 217-20 (repr. from J. B. Lyons [ed.], 2000 years of Irish medicine [Dublin, 1999], pp 21-6). Nic Dhonnchadha's work more broadly constitutes a key exception to the general neglect of Irish-language medical writing; in recent years, for example, she has produced several important new catalogues of individual Irish medical manuscripts, many of which can be viewed on the Irish Script on Screen database (www.isos.dias.ie).

${ }^{4}$ Robin Flower, 'Popular science in medieval Ireland' in Ériu, ix (1921/23), pp 61-7.

${ }^{5}$ See Deborah Hayden, 'Three versified medical recipes invoking Dían Cécht' in Anders Ahlqvist and Pamela O'Neill (eds), Fir fesso: a festschrift for Neil McLeod (Sydney, 2018), pp 107-23; eadem, 'Attribution and authority in a medieval Irish medical compendium' in Studia Hibernica, xlv (2019), pp 19-51, at pp 32-4; and eadem, 'A versified cure for headache and some lexicographical notes' in Keltische Forschungen, viii (2019), pp 7-22.

${ }^{6}$ The above figures are based on a draft transcription of the full text recently completed by Dr Siobhán Barrett, for whose input I am very grateful. A recent codicological study of this treatise by Aoibheann Nic Dhonnchadha, 'An Irish medical treatise on vellum and paper from the $16^{\text {th }}$ century' in Pádraig Ó Macháin (ed.), Paper and the paper manuscript: a context for the transmission of Gaelic literature (Cork, 2019), pp 111-25, has demonstrated that some of its leaves became separated from their original codex at an unknown point in its transmission, with the result that the thirty-two vellum leaves comprising the majority of the text are still found in their original location (R.I.A., MS 24 B 3 [445], pp 33-[90], 90a, 90b and 91-3), while a further eight paper leaves are now bound up as part of a second, composite codex, namely R.I.A., MS 23 N 29 (467), ff 1-4 and 6-9. Nic Dhonnchadha established the correct collation of these leaves as follows:

$$
\begin{aligned}
& \text { R.I.A., MS } 24 \text { B } 3 \text { (445), pp 33-70; } \\
& \text { R.I.A., MS } 23 \text { N } 29 \text { (467), ff 1-4; } \\
& \text { R.I.A., MS } 24 \text { B } 3 \text { (445), pp 71-4; } \\
& \text { R.I.A., MS } 23 \text { N } 29 \text { (467), ff 6-9; } \\
& \text { R.I.A., MS } 24 \text { B } 3 \text { (445), pp 75-93. }
\end{aligned}
$$


sources of the fifteenth and sixteenth centuries to have belonged to the hereditary family of medical practitioners of that name active primarily in the region of north Connacht during the late-medieval period. References in the surviving Irish manuscripts to members of the Mac an Leagha family and the written works they produced were first documented by Paul Walsh, who noted that Conla was most likely the brother of Maeleachlainn Mac an Leagha, an ollamh (professor) in medicine to the Mac Donnchaidh lords based in Ballymote and Tirerrill, County Sligo. ${ }^{7}$ Conla himself is known to have been a practising physician in the service of the Mac Diarmada family in the nearby lordship of Magh Luirg, located in what are now the baronies of Boyle and Frenchpark, County Roscommon, and he appears to have moved around to several different locations in that area while compiling his book of remedies, seemingly for his own use. ${ }^{8}$ His collection draws on a wide variety of different sources of varying antiquity; most of these are transmitted anonymously, but occasional explicit references to particular texts or authorities demonstrate that he was familiar with both the standard medical learning current in the latemedieval universities, as well as with more local authorities and traditions. ${ }^{9}$

Conla Mac an Leagha's remedy book was first identified, in a survey article published in 1990, as 'an apparently unique text' within the extant corpus of premodern Irish medical writing on the basis that it contains both prose and verse material. ${ }^{10}$ Its contents have not been the subject of any substantial discussion since that time, however, with two key exceptions being the aforementioned editions of five separate poems and some analysis of eight charms preserved in the chapters on ailments of the head, eyes, nose and teeth. ${ }^{11}$ The present contribution focuses on one hitherto unpublished versified remedy that consists of a simple herbal cure for dropsy and pulmonary ailment. While this eight-stanza composition may at first glance seem to constitute a rather unremarkable specimen of medieval herbal lore, its publication in full here can nevertheless be said to add another small puzzle piece to our understanding of the nature and scope of the didactic medical verse preserved in Irish

${ }^{7}$ Paul Walsh, 'An Irish medical family - Mac an Leagha' in Colm Ó Lochlainn (ed.), Irish men of learning (Dublin, 1947), pp 206-18, at p. 210.

${ }^{8}$ Walsh, 'An Irish medical family', p. 214; Nic Dhonnchadha, 'An Irish medical treatise', p. 113.

${ }^{9}$ These citations are discussed in more detail in Deborah Hayden, 'Attribution and authority'.

${ }^{10}$ Aoibheann Nic Dhonnchadha, 'Early modern Irish medical writings' in Scéala Scoil an Léinn Cheiltigh/Newsletter of the School of Celtic Studies, Dublin Institute for Advanced Studies, iv (1990), pp 35-9, at p. 36.

${ }^{11}$ Eight charms from the text were published by James Carney and Maura Carney, 'A collection of Irish charms' in Saga och Sed: Kungliga Gustav Adolfs Akademiens Arsbok (1960), pp 144-52, and some of these have since been revisited by other scholars: see, for example, David Stifter, 'Zur Bedeutung und Etymologie von altirisch sirem' in Die Sprache, xlv, no. 1-2 (2005), pp 160-89; idem, 'A charm for staunching blood' in Celtica, xxv (2007), pp 251-4; Jacqueline Borsje, 'Medieval Irish spells: "words of power" as performance' in Ernst Van den Hamel and Asja Szafranic (eds), Words: religious language matters (New York, 2016), pp 35-53; eadem, 'Celtic spells and counterspells' in Katja Ritari and Alexandra Bergholm (eds), Understanding Celtic religion: revisiting the pagan past (Cardiff, 2015), pp 9-50; and Deborah Hayden, 'Old English in the Irish charms' in Speculum, xcvii, no. 2 (forthcoming April 2022). Several important observations concerning the contents of the treatise are also made by Aoibheann Nic Dhonnchadha, 'Michael Casey's medical transcripts in Gilbert MS 147' in Éigse, xl (2019), pp 43-114, at pp 7585 (considered further below). 
manuscript sources. This particular poem is also of interest, however, because it provides intriguing evidence for the transmission of knowledge recorded in the extant premodern Irish medical manuscripts well into the nineteenth century, when a quatrain from it came to be invoked as a symbol of the antiquity and authority of medieval Irish medical learning on a broader level.

The versified remedy in question is one of several poems included in a chapter of Conla Mac an Leagha's remedy book that deals primarily with ailments affecting the chest and respiratory system. It is found near the end of this section, the beginning of which is marked by a large space at the bottom of p. 59 in R.I.A. MS 24 B 3, where room has been left for the initial letter ' $\mathrm{D}$ ' in the opening phrase Do gallraib na scaman ('On ailments of the lungs') to be filled in. In the presentation of the text of the poem below, expansions are indicated by italics, and length-marks, where not found in the manuscript, have been supplied using a macron over vowels. Word-division and punctuation are editorial.

\section{R.I.A. MS 24 B 3 (445), pp 65.33-66.5:}

A lucht an leighis gan lēn

abraid rim gan imarscáil

leigheas īccus imalle

attcomoll 7 loch tuile.

Crūadaigter bun ragum rēil

re tes tened nó re gréin.

Melar lān cingidi de

conad men, cona gairbe.

Doberur a lān ele

do men phsalainn cu nglaine

7 a dalān malle

do linn sīrglan, sengruidne. ${ }^{12}$

Curther bec do garbān fair

corci nó eōrna fo bhail
O people of healing without misfortune,

relate to me without contending

a cure which heals

both dropsy and ailment of the lungs.

A root of horse-radish is dried at the heat of a fire or in the sun.

A cupful of it is ground

So that it is neither too fine nor too rough.

Another quantity of fine salt

Is placed [in it] clearly,

and along with it a good amount

of ever-bright liquid, of stale butter.

A small amount of coarse meal is put upon it

Oats or barley with good effect

12 The manuscript reads sirgruidne here, but the first element of the compound is glossed nó sen ('or sen-'), suggesting that the scribe thought it should read sengruidne. I have taken this to mean 'stale butter', since other remedies from Conla Mac an Leagha's text include the ingredient gruiten, defined in the historical dictionary of the Irish language $(e D I L)$ as 'stale butter; salt butter; small curds which remain mixed with the whey after the removal of the thicker substance': see Gregory Toner, Máire Ní Mhaonaigh, Sharon Arbuthnot, Marie-Luise Theuerkauf and Dagmar Wodtko (eds), eDIL: Electronic dictionary of the Irish language (hereafter eDIL), s.v., gruiten (dil.ie/26728) (7 May 2021). A citation under the eDIL entry for the word gruth (dil.ie/26734) (7 May 2021), which has the similar meaning of 'curds, cheese', demonstrates that this term was likewise used to form a compound with the prefix sen- 'old'; this citation is drawn from the Middle Irish narrative Aislinge meic Con Glinne, which recounts a vision of a land made entirely of food (i.e. tar srónaib sengrothai, 'past headlands of old curds'). 
doberur i n-aighen nglan na nethe $\sin$ is berbthaur.

As ē sin an teguscc cōir arna mberbad: fo cétoir a tabairt a lestur nglan fo faircle 7 fo iadad.

Deocha mōra gan meabail is techda d'ōl na degaid do cuirm nó do medg gan acht nó d'uisce fuar fîrtiprad.

Colmān mac Oililla aīn as ē tug a nInis Fāil mar do ordaig Rīg na rand

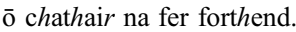

Is maith ar loch tuile trēn

7 ar atchomoll, nī chēl as iat arada gan geis a luchd luchar an leighis.
Those things are placed in a clean vessel, and it is boiled.

That is the proper instruction after boiling it: immediately put it in a clean vessel under a lid and a cover.

Afterwards it is proper to drink big draughts without shame of beer or of whey without doubt or of cold water from a pure source.

Fair Colmán son of Oilill

It is he who brought [this knowledge] to Ireland as the King of the stars ordained from the settlement of the very strong men.

It is good for severe ailment of the lungs and from dropsy, I will not hide it. Those are treatments without flaw O resplendent people of healing.

The final stanza of this versified remedy makes it clear that the cure was understood to be effective for two ailments in particular, namely atchomall and loch tuile. According to $e D I L$ (s.v.), the word atchomall can refer to a variety of medical afflictions 'involving swelling or inflammation of parts of the body', or 'dropsy'. ${ }^{13}$ One of the citations given in that source - from an Irish medical glossary preserved in a seventeenth-century manuscript - explicitly equates the term with Latin hydropisis, a word that is itself derived from Greek hydor 'water'. ${ }^{14}$ On the basis of teaching found in several Latin therapeutic manuals (or practicae) of the late-medieval period, Luke Demaitre has described hydropisis as 'a broad disease category that was generally difficult to cure, and that was attributed to hepatic malfunction', similar but not identical to the modern category of oedema (the swelling of soft tissues from the accumulation of excess fluid). ${ }^{15}$ This no doubt gives some clue as to the medical problem intended to be cured by a separate versified remedy of five quatrains that immediately follows our poem in the treatise: for that composition, which is instead attributed to the chief legendary healer-figure of early Irish literary

13 http://www.dil.ie/4582 (7 May 2021); 'dropsy' is defined in the Oxford English Dictionary (www.oed.com, s.v.) as 'a morbid condition characterized by the accumulation of watery fluid in the serous cavities or the connective tissues of the body' (cf. the more modern term 'oedema/edema').

14 This glossary is found in John Rylands Library, University of Manchester, Irish MS 35, ff 117a1-118a1: see Whitley Stokes, 'Three Irish medical glossaries' in Archiv für celtische Lexicographie, i (1899), pp 325-47, at p. 337 (\$136): Ismorfea .i. atchomall nó idhropis. It is noteworthy, in this regard, that the chapter in Conla Mac an Leagha's treatise that immediately follows that in which his remedies for atchomall are found begins Don idropis: R.I.A., MS 24 B 3, p. 72.20. It is unclear whether the terms were understood to be synonymous or not, but given that the treatise seems to be a compilation, it is possible that the juxtaposition of these two sections reflects the conflation of remedies from different sources that use variant terminology for the same ailment.

${ }^{15}$ Luke Demaitre, Medieval medicine: the art of healing, from head to toe (Santa Barbara, CA, 2013), p. 277. 
tradition, Dían Cécht, begins with the words Cìa in deoch cāolas an corp cauin/ do-ordaig Diaan Cécht cobsaidh? ('What is the potion that makes the fair body thin/which steadfast Dían Cécht prescribed?'). ${ }^{16}$

The authors of several Latin practicae, including the twelfth-century Salernitan physician Platearius, the English physician Gilbertus Anglicus (c.1180-c.1250), and the French physician Bernard of Gordon ( $f$. 1270-1330), identified four principal types of hydropisis, each of which was distinguished by the nature of the humoral and qualitative imbalance responsible for it. These were termed leucoflegmantia (caused by excessive cold and humidity of the liver), hyposarca or anasarca (caused by excessive cold and dryness), ascites (caused by warmth and humidity) and timpanites (caused by warmth and dryness). ${ }^{17}$ Familiarity in an Irish context with this fourfold scheme, as well as the humoral theory which underlies it, is evident from other remedies in Conla Mac an Leagha's collection. For example, the longest poem in the treatise, which is a composition of twenty-three quatrains occupying a full manuscript page, cites the Latin names for all four types of the disease. ${ }^{18}$ On the following page of the text, moreover, the scribe inserted an interlinear comment between various remedies for atchomall that reads cuit na teasaidechta gu nuige sin. Cuid na fuaraidechta anois (lit. 'the part of heat up to there. The part of cold now'), indicating that the cures for atchomall listed in the treatise up to that point may have been intended for the varieties of hydropisis caused by excessive heat (i.e. ascites and timpanites), while those that follow the comment were understood as being for the types of the disease caused by excessive cold (hyposarca and leucoflegmantia). ${ }^{19}$

On the preceding six pages of the treatise, numerous other cures in both verse and prose are given for loch tuile, the second ailment for which our remedy is claimed to be efficacious. Although the term loch tuile is not recorded in any published lexicographical sources for the Gaelic languages, the fact that it designated some kind of pulmonary affliction, or more likely a variety of different ailments affecting the lungs, is evident from the opening words of the chapter of the text in which these remedies are found: namely, Do gallraib na scaman ('on diseases of the lungs'). ${ }^{20}$ It is likewise noteworthy that the ingredients prescribed in our versified remedy - in particular, the root of the plant ragam (probably 'horseradish'), which is to be dried and ground, mixed with salt and stale butter or curds, and boiled with coarse meal to make a drink for the patient - are also found in a separate prose remedy in this section that is stated to be useful for various problems affecting the chest. $^{21}$

${ }^{16}$ For the full poem, see Hayden, 'Three versified medical recipes', p. 110.

${ }^{17}$ Demaitre, Medieval medicine, p. 277.

18 R.I.A., MS 23 N 29, f. 4v (beg. A lega Banba na mbrat): isposarca (4v4); timpanites (4v9); leuca...flegmaticus (4v13); alsites (4v15). The content of this poem has also been noted by Nic Dhonnchadha, 'Michael Casey's medical transcripts', p. 81, n. 75.

19 R.I.A., MS 24 B 3, p. 71.15.

${ }^{20}$ R.I.A., MS 24 B 3, p. 59.34. The term loch tuile is discussed in more detail in Deborah Hayden, 'The lexicon of pulmonary ailment in some medieval Irish medical texts' in Zeitschrift für celtische Philologie, lxvi (2019), pp 105-29.

${ }^{21}$ R.I.A., MS 24 B 3, p. 62.11-13: Cosc ar mūchad 7 ar ghabail anāla 7 ar leic 7 ar anmande craide .i. ragam 7 men psalaind air 7 gruden ind 7 ebar fo laige 7 fo erge, "A cure for asthma and for shortness of breath and for stone and for weakness of the heart, i.e. [take] horseradish (ragam) and [put] finely ground salt on it and [put] stale butter in it and drink when going to sleep and rising'. On the meaning of gruden, see above, n. 13. 
III

In many respects, however, the most interesting aspect of our medical poem is its penultimate quatrain, in which one 'Colmán mac Oililla' (Colmán, son of Oilill) is invoked as an authority for the remedy as a whole. In a recent analysis of authoritative attributions attached to various prose and verse remedies in Conla Mac an Leagha's text, I suggested that the Colmán invoked here might be identified with one of two individuals bearing both this name and patronymic who are noted in Irish annal entries of the early medieval period. ${ }^{22}$ The first of these is recorded in the Annals of the Four Masters (A.F.M.) as having died in 823, having been abb Slaine \& ecclas oile archéna isin f-Frainc \& $i$-Eirinn ("Abbot of Slaine, and also of other churches in France and Ireland'). ${ }^{23}$ The second reference is to a 'Colmán mac Aililla' who died at the end of the first quarter of the tenth century:

\section{A.F.M., s.a. 924:}

Colman, mac Aililla, abb Cluana Ioraird, \& Cluana Mic Nóis, espucc, \& doctor egnaidh, d'ég. As leis do-rónadh daimh liac Cluana Mic Nóis. Do Chonaillibh Muirtemhne a chenel.

Colman, son of Ailill, Abbot of Cluain-Iraird and Cluain-mic-Nois, a bishop and wise doctor, died. It was by him the Daimhliag of Cluainmic-Nois was built; he was of the tribe of the Conailli-Muirtheimhne. ${ }^{24}$

\section{Annals of Ulster, s.a. 926:}

Colman, princeps Cluana Iraird \& Cluana M. Nois, \& scriba \& episcopus, in Christo quieuit.

Colmán, superior of Cluain Iraird and Cluain Moccu Nóis, and a scribe and bishop, rested in Christ. ${ }^{25}$

This second Colmán mac Aililla had been abbot of Clonard since 888 and of Clonmacnoise since 904, and has been argued to have played an important part in the transmission of annalistic writing. He may also have been responsible for erecting the famous Cross of the Scriptures at Clonmacnoise in cooperation with the Uí Néill king Flann Sinna in $909 .{ }^{26}$ The A.F.M. entry notes in particular that this Colmán was involved in the construction of a stone church (daimliag) at Clonmacnoise, a building that may have reflected Flann Sinna's patronage of that ecclesiastical settlement.

In my study of authorities mentioned in Conla Mac an Leagha's medical text, I ultimately drew no firm conclusion as to which of these two abbots, if either, might be the Colmán mac Aililla claimed to be an authority for the medical remedy published here. In a separate discussion of the treatise, Aoibheann Nic Dhonnchadha

22 Hayden, 'Attribution and authority', pp 36-8.

23 A.F.M., i, s.a. 823.8 .

24 A.F.M., ii, s.a. 924.

25 Seán Mac Airt and Gearóid Mac Niocaill (eds and trans.), The Annals of Ulster, to AD 1131 (Dublin, 1983), s.a. 926.

${ }^{26}$ See F. J. Byrne, 'The trembling sod: Ireland in 1169' in Art Cosgrove (ed.), A new history of Ireland, II: medieval Ireland 1169-1534 (Oxford, 1987), pp 1-42, at p. 9. 
stated that the figure in question should be identified with the Colmán mac Aililla who died in 926, but offered no specific justification for this assertion. ${ }^{27}$ The description of the tenth-century abbot of Clonard and Clonmacnoise as an espucc, $\&$ doctor egnaidh ('bishop and wise doctor') in the Annals of the Four Masters provides no certain clues as regards any medicinal expertise on his part, since the term doctor was used frequently in annalistic entries between the eighth and tenth centuries as a rather broad reference to someone who 'combined their scholarship with pedagogical, liturgical and preaching roles'. On this basis, Elva Johnston has argued that the usage of the Latin word during that period should be set in the context of ecclesiastical developments that were taking shape in Ireland from the early eighth century. ${ }^{28}$

Although it sheds little light on the matter of which of these two figures named 'Colmán mac Aililla' - if either - might be the one cited in our poem, it is however noteworthy that another versified cure for loch tuile, given on the preceding page of Conla's text, states in its final quatrain that Ailill Mael rofagaib sin ('Ailill the bald/tonsured left that [cure]'). ${ }^{29}$ The text offers no clues as to whether this 'Ailill Mael' might have been the father of the Colmán cited in our poem, but given what we know of the largely hereditary nature of medical practice in medieval Ireland, as well as the fact that these two attributions occur in the same chapter of Conla's treatise and only a page apart, one might speculate that the authorities in question were father and son, and that the versified remedies for pulmonary ailments that are attributed to them derive from a source connected with that particular family of practitioners. That Conla may have relied heavily on one specific source for the medical recipes in this section of his treatise may also be indicated by the fact that his chapter of cures for chest afflictions contains a relatively large number of versified remedies when compared with other sections of the treatise. Indeed, it begins with a sequence of no less than seven poems, most of which are clearly marked by the addition of the word dúan at the beginning of each composition in the margin of the manuscript page. ${ }^{30}$

Other authoritative attributions found in this and other parts of Conla Mac an Leagha's text suggest that some of the sources available to him may have been specifically associated with the north-eastern region of Ireland. For example, a separate remedy for loch tuile is attributed to an unnamed 'abbot of Bangor', which is most likely a reference to a head of the monastic foundation established in the sixth century in what is now County Down. ${ }^{31}$ Similarly, a cure for an eye ailment found elsewhere in the treatise is explicitly associated with the king (ri) of Dál nAraide, a kingdom located in what is now County Antrim. ${ }^{32}$ These attributions may lend some support to the tentative identification of the 'Colmán Mac Oililla' cited in our poem with the tenth-century abbot of Clonard and Clonmacnoise, since the A.F.M. entry explicitly notes that the latter figure was originally from Conaille

${ }^{27}$ Nic Dhonnchadha, 'An Irish medical treatise', p. 118.

28 Elva Johnston, Literacy and identity in early medieval Ireland (Woodbridge, 2013), pp $112-19$.

${ }^{29}$ R.I.A., MS 24 B 3, p. 64.21. I am grateful to Siobhán Barrett for drawing my attention to this reference.

${ }^{30}$ R.I.A., MS 24 B 3, pp 59-61.

${ }^{31}$ For this reference, see R.I.A., MS 24 B 3, p. 64.33-2, and Hayden, 'Attribution and authority', p. 38.

${ }^{32}$ See Siobhán Barrett, 'Varia I. The king of Dál nAraidi’s salve' in Ériu, lxix (2019), pp $171-8$. 
Muirthemne, a kingdom located in the north of what is now County Louth that emerges in the historical record in the late seventh century, and disappears from it c.1100. David Thornton has observed that notices in the genealogies pertaining to this population group indicate that they were at some point classed as 'Cruithni', a term applied to a number of territories in north-east Ireland, including that of the kingdom of Dál nAraide. ${ }^{33}$

\section{IV}

The precise identity of the 'Colmán mac Oililla' invoked as an authority for the versified remedy published above thus still cannot be determined with any real certainty on the basis of the evidence currently available. However, the quatrain of the poem in which he is named is also of interest on account of the fact that copies of it are found in two other, much later sources dated to around the first half of the nineteenth century. The stanza thus offers a rare glimpse into the continued use and transmission of the medical learning in Conla Mac an Leagha's manuscript well into the modern period, and provides some insight into the value placed on the premodern Irish medical manuscripts in later antiquarian circles. When considered in light of one another, moreover, the three extant witnesses of this quatrain offer an interesting case study of the relationship between manuscript, print and material culture in Ireland during the early nineteenth century.

One of the two later sources in which the stanza is found has recently been noted by both Aoibheann Nic Dhonnchadha and the late Richard Sharpe in a pair of companion articles, the aim of which was to offer a detailed account of the life and work of the Munster scribe and 'herb doctor' Michael Casey (1752?-1830/31). ${ }^{34}$ As Sharpe observed, Casey's 'small claim to fame' was perhaps best described by the nineteenth-century antiquarian John O'Donovan, who wrote in 1845 that 'he was an herb doctor in Dublin in his old age, and discovered a cure for the gout in some old Medical Irish MS. of which he made great noise in the newspapers in the years 1824, 1825, \&c' ${ }^{35}$ Casey had lived for some time in Myler's Alley, close to St Patrick's Cathedral in Dublin, and was cited by Rev. Robert Walsh (1772-1852) in the latter's account of medical practice in Dublin around 1818, as one of a handful of noteworthy 'irregular practitioners' working in the city at that time. Walsh further claimed that Casey was in possession of a large number of Irish manuscripts from which he derived his remedies, and advertised his services by way of 'an angular sign board projecting from the wall' on which was

${ }^{33}$ David E. Thornton, 'Early medieval Louth: the kingdom of Conaille Muirthemne' in Louth Arch. Soc. Jn., xxiv, no. 1 (1997), pp 139-50, at pp 147-8; see also idem, Kings, chronologies and genealogies: studies in the political history of early medieval Ireland and Wales (Oxford, 2003), chap. 6; Laurence P. Murray, 'The Pictish kingdom of Conaille-Muirthemhne' in John Ryan (ed.), Féilscribhinn Eóin Mhic Néill: essays and studies presented to Professor Eoin MacNeill on the occasion of his seventieth birthday, May $15^{\text {th }}, 1938$ (Dublin, 1940), pp 445-53; and idem, 'The ancient territories of Oirghialla, Uladh and Conaille Muirthemhne' in Louth. Arch. Soc. Jn., iii, no. 1 (1912), pp 52-65.

${ }^{34}$ Richard Sharpe, 'Michael Casey (?1752-1830/31), herb doctor, Irish manuscripts, and John O'Donovan' in Éigse, xl (2019), pp 1-42, and Nic Dhonnchadha, 'Michael Casey's medical transcripts'.

${ }^{35}$ Sharpe, 'Michael Casey', pp 1 and 10, quoting from a note by John O'Donovan on the first page of T.C.D., MS 1398/2, a manuscript apparently written by Michael Casey himself. 
inscribed 'Domestic Medicine prescribed from Irish Manuscripts', followed by a couplet of Irish poetry reading A Chriost leigheas an lag/Guidhim ort a g-cabhair ('Oh! Christ the sick relieve/to their aid I thee implore'). ${ }^{36}$ Sharpe suggested that this signboard may have been very widely known in his own time, since the same couplet is quoted in a manuscript from Belfast, written in 1818, where Casey is described as 'an Erbinest [herbalist] or Doctor \& Botinist \& also a very fine Irish writer Manascript scollar \& cures all by Erbes'. ${ }^{37}$

Michael Casey's renown as both a 'Doctor \& Botinist' and a 'Manascript scollar' was clearly not unfounded, since Sharpe was able to demonstrate that he had written, owned, borrowed or otherwise used some nineteen identifiable Irish manuscripts, many of them primarily medical in content. ${ }^{38}$ In or around 1831, several of Casey's extracts and papers were bound together into what is now Dublin City Library and Archive, Gilbert MS 147, the contents of which are the focus of the Aoibheann Nic Dhonnchadha's study. ${ }^{39}$ On the basis of 'two specific instances in which Casey can be shown to have translated material' from R.I.A., MS 24 B 3 - that is, the manuscript containing the bulk of Conla Mac an Leagha's prosimetrical remedy book, including the poem published in full here - Nic Dhonnchadha confirmed that this manuscript was indeed among the codices known to Casey. ${ }^{40}$ For example, she drew attention to the fact that, in an extract from Gilbert MS 147, Casey refers to a certain 'Niele ô Kearney who wrote on the Circulation of the Blood', a citation that might be linked to the signature of a 'mac neil i cearrnuid .i. davi' ('the son of Niall Ó Kearney, i.e. Davi') that is written in rasura on p. $65 \mathrm{z}$ of R.I.A., MS 24 B $3 .{ }^{41}$

Of particular interest to this discussion is the second of the two passages noted by Nic Dhonnchadha as having been excerpted by Casey from R.I.A., MS 24 B 3, since this passage can be identified as the penultimate stanza of our poem. ${ }^{42}$ Casey included this quatrain in the prospectus for his Athanasia Hibernica, an Irish herbal based on remedies found in Irish vellum manuscripts, that he had intended to publish in several instalments $c .1825{ }^{43}$ While the entire text of this herbal appears not to have survived and there is no clear evidence to suggest that it was ever actually published, copies of a prospectus for it are known to be extant. ${ }^{44}$

${ }^{36}$ Sharpe, 'Michael Casey', pp 1-2.

37 Ibid., pp 2-3, quoting from N.L.I., MS G 199, p. 224.

38 A list of these is given in Sharpe, 'Michael Casey', pp 35-9.

39 Nic Dhonnchadha, 'Michael Casey's medical transcripts', p. 43.

40 Ibid., p. 78.

${ }^{41}$ Ibid., p. 77. Nic Dhonnchadha suggests that Casey may have been generalising in his reference to the work of 'Neile ô Kearney', since no text dealing specifically with 'the circulation of the blood' is found in R.I.A., MS 24 B 3. She argues that the 'davi' noted on p. 65 of R.I.A., MS 24 B 3 as being the son of this figure might be identified as Dáibhí Ó Cearrnaigh, a scribe whose name is recorded under the year 1563 in a separate miscellany of medical material; on this figure, see also Nic Dhonnchadha, 'An Irish medical treatise', pp 113-15.

42 It is probably no coincidence that this stanza is written on the page of 24 B 3 that immediately follows the aforementioned signature of 'mac neil i cearrnuid .i. davi' on p. 65 of the manuscript (which contains the first five quatrains of the poem).

${ }^{43}$ Sharpe, 'Michael Casey', p. 20.

${ }^{44}$ Sharpe, p. 20, n. 53 states that 'The only known specimen of this prospectus belonged to the late Dr Maura Scannell, of the National Botanic Gardens, Glasnevin, who died in 2011. It is to be hoped that it will come to light when her papers are catalogued'. Both Sharpe and Nic Dhonnchadha had, however, been able to consult a scan of the prospectus made by Dr Scannell and sent to Prof. Pádraig de Brún in 1987. I am very grateful to Alexandra Caccomo at the library of the National Botanic Gardens for forwarding a copy of this 
Having consulted one of these copies, Nic Dhonnchadha reproduced the relevant section of the prospectus as follows:

For it is manifest that St. Coleman M'Elle, a contemporary of St. Colomba, went to Grand Cairo, and brought persons from thence to Ireland, who had a traditional treatment of the management of plants, pursuant to Solomon's system; which is authenticated by the following verse:

Colmán mac Oililla áin. A sé thug an Inis Fáil.

Mar d'orduigh Righ na ran̄; ó chathair na bhfear foirthean̄. ${ }^{45}$

Nic Dhonnchadha further observed that Casey's citation of this stanza in his prospectus is of some significance insofar as it constitutes 'an early instance of the appearance in print of a quotation from an Irish medical manuscript, and the first of a quatrain from an Irish medical poem'. ${ }^{46}$

From the brief remarks that preface Casey's transcription of this quatrain, it would appear that he included this particular stanza of poetry in the prospectus for his Athanasia Hibernica because he thought that it provided a fitting illustration of the antiquity of Irish medicinal plant lore. This hypothesis is confirmed by the passage in the prospectus that immediately precedes the extract cited above, in which Casey offered a fuller justification for his use of earlier Irish-language medical manuscripts as a source for the remedies in his herbal:

The editor, or rather the translator of this proposed work, doth not intend to hurt any person by the publication, but to serve the poor, who would be in the greatest distress, and far from any doctor or skilful person to relieve him from his misery, and at the same time his cure perhaps growing within a few yards of his cabbin, a heavenly gift yearly presented by the Lord for such purpose, where a man of some knowledge, nay even a skilful and charitable housewife, by comparing his complaint to the symptoms described in this work, might alleviate the disease for a time. Even diseases which have baffled the skill of a Physician, have yielded to the traditional treatment of the illiterate, armed with the most simple of our plants [...] It may be also alleged by somebody, who would say, if such publication as this be true, how is it possible we could have lost this valuable production? By this question, he declares himself quite ignorant of the history of this kingdom; and the more so if he did; for he would find, that in the reign of king Tigernmas,

scan to me, and for renewing the (as yet still unsuccessful) effort to locate the original document in the library archives. Subsequent to this, I was also able to consult at least some of Dr Scannell's notes on the Athanasia Hibernica, which can be found in N.L.I., MS 50,654 (my thanks to an anonymous reader for this reference). Scannell appears to have been primarily engaged in researching John Keogh's Botanologia Universalis Hibernica, a text that was first published in 1735, and a second edition of which was advertised alongside Casey's Athanasia Hibernica in the prospectus. In her notes, Scannell observed that the prospectus was 'printed on both sides of a single octavo sheet measuring $27 \mathrm{~cm} \mathrm{x} 45 \mathrm{~cm}$, [and] carries neither watermark nor date of proposed publication of either title. It appears that the project [of publishing the Athanasia Hibernica] was abandoned due perhaps to lack of support from subscribers.'

${ }^{45}$ Nic Dhonnchadha, 'Michael Casey's medical transcripts', p. 78. For a translation of the verse in this passage, see above.

46 Ibid., p. 78, n. 67. 
(long before we had Christianity here) there was a gold-mine at Liffey-head, and refined there: also, that the silver of the helmets of 27,000 men (the standing army of Ireland, when the Romans invaded England) was got in Airgiod-Ross, and gold at Liffey-head, which was re-worked not quite 50 years ago. We may suppose that the ore was not exhausted from those places no more than the treasury of health from this work. ${ }^{47}$

Here, Casey hints at familiarity with references in medieval Irish manuscripts to the legendary high king of Ireland, Tigernmas, whose reign, according to A.F.M. and the medieval Irish pseudo-historical text Lebor gabála Érenn, was distinguished by several inventions or innovations, including the first smelting of gold; the production of the first brooch and of horns and silver vessels; and the first dyeing of clothes in different colours. ${ }^{48}$ Although Casey is not explicit on the matter, it is possible that his subsequent reference to the herbal lore preserved in Irish manuscripts as being 'pursuant to Solomon's system' alludes to I Kings 4:33, where, in an account of the wisdom and insight attributed to the biblical king Solomon, it is claimed that the latter 'spoke about plant life, from the cedar of Lebanon to the hyssop that grows out of the walls'. However, it may also be significant that Lebor gabála Erenn synchronises the reign of the Irish king Tigernmas with those of Solomon and David. ${ }^{49}$ Casey's reference to medical experts brought to Ireland from 'Grand Cairo' is likewise rather cryptic, but could simply constitute another allusion to the wisdom of Solomon, and perhaps more specifically to the Eastern origins associated with certain plants and remedies preserved in the Irish medical manuscripts: he may have been aware, for example, of cures found elsewhere in Conla Mac an Leagha's text that are explicitly said to be derived as tir toir 'from the land in the east' and a tirib Greg 'from Greek lands'. 50

The contents of the prospectus for Casey's Athanasia Hibernica shed even less light, however, on the source for his claim that the 'St Coleman M'Elle' (or 'Colmán mac Oililla') cited in the stanza of verse was a 'cotemporary of St Colomba', who lived in the sixth century. I have been unable to find any reference to a 'Colmán' bearing the relevant patronymic who was associated with such an early period. If Casey was drawing directly on the R.I.A., MS 24 B 3 witness of Conla's remedy collection for his transcription of the quatrain, and had consulted other prose and verse remedies in that section, one might hazard a guess that he made a connection between the 'Colmán mac Oililla' of our poem and the attribution of another cure for loch tuile to an unnamed 'abbot of Bangor', as noted above, since the Irish annals record that one 'Colmán, abbot of Bangor' died in the year 680 - a period that is at least somewhat closer in time to that in which $\mathrm{St}$ Columba, the alleged 'cotemporary' of Casey's 'St Coleman M'Elle', would have lived. ${ }^{51}$

47 The passage then continues on immediately with the extract cited by Nic Dhonnchadha and reproduced above.

${ }^{48}$ See A.F.M, i, s.a. 3656, and R. A. S. Macalister (ed. and trans.), Lebor gabála Érenn: the book of the taking of Ireland (5 vols, Dublin, 1932-42), v, 202-09.

${ }^{49}$ Macalister (ed. and trans.), Lebor gabála Érenn, v, 209.

${ }^{50}$ These references are noted by Nic Dhonnchadha, 'Michael Casey's medical transcripts', p. 78, n. 68 .

${ }^{51}$ See e.g. Annals of Ulster, s.a. 680: Colman, abbas Benncair, pausat. Kathleen Hughes, The church in early Irish society (London, 1966), p. 93, has tentatively suggested that this Colmán may be identical with the scholar named 'Calmanus' who, in a letter probably 
The question of whether Casey was drawing directly on the 24 B 3 manuscript witness for his transcription of the stanza in his prospectus cannot be established with absolute certainty on the basis of the textual evidence given above, since he does not give an exact source for the quotation, and close comparison of the two versions of the text reveals some minor orthographical discrepancies. For example, in the version of the quatrain given in the prospectus, Casey has added dots over letters that one would expect to be lenited, even though these diacritics are not present in the manuscript witness (for example, he gives the form tug in place of the manuscript reading tug, and Rig in place of the manuscript reading rig) ${ }^{52} \mathrm{He}$ also gives the form d'orduigh in place of the manuscript reading do ord, thus expanding the final part of the word that has been abbreviated with a suspension mark in the manuscript, and eliding the final vowel of the preposition $d o$ and the initial vowel of the verb. The manuscript reading na fer is written by Casey as na bfear, showing both the expected nasalisation at the beginning of a genitive plural noun following a definite article, as well as the glide vowel marking absence of palatalisation on the final consonant. Finally, the manuscript readings rand and forthend are written by Casey as rañ and foirtheán respectively, where the suspension mark over the ' $\mathrm{n}$ ' presumably indicates the double nasal $-n n$, often written interchangeably with $-n d$ in medieval texts.

It is of course possible that Casey simply introduced these changes to the manuscript text in a deliberate attempt to render the latter more easily comprehensible to an audience familiar with written Irish of the early nineteenth century, and perhaps especially in an effort to spare his readers the difficulty of navigating the large number of (often ambiguous or obscure) contractions found in many medieval Irish medical manuscripts. Indeed, Casey alludes to just such a purpose in the opening words of his prospectus, where he explains that he has chosen to provide an English translation alongside the original Irish text of the remedies included in his herbal, and that this text (presumably he is referring to the original Irish version of the remedies here) will be

free from hieroglyphics, physical or pharmacopolic contractions, as generally is the case - but plain and easy for the reader. This is merely adduced, not

written in the seventh or eighth century, informed his 'most dear and learned son' Feradad that his community had obtained a number of manuscripts from the Romani (those who followed the Roman Easter), and that these manuscripts contained better texts than the ones he and his pupil already possessed. Hughes noted that the letter in question 'illustrates how improved recensions of works available outside Ireland must have been obtained and circulated' in the early medieval period. If her identification is correct, it would indicate that the Colmán who was abbot of Bangor in the seventh century, where an active scriptorium was already in place, could also have had some particular renown as someone who imported new knowledge into Ireland; however, it is unclear where Michael Casey might have obtained this information.

52 In Nic Dhonnchadha's citation of the quatrain in Casey's prospectus, quoted above, the punctum delens over these letters is represented by a ' $\mathrm{h}$ ' immediately after the consonant, as is standard editorial practice in expanding marks of lenition in manuscripts; however, Casey's use of the suprascript dot rather than a ' $h$ ' is significant for what follows in this discussion. It is worth noting that Conla Mac an Leagha quite regularly omits marks of lenition elsewhere in his prosimetrical remedy collection, whether in the form of a suprascript dot over the relevant consonant or of a ' $h$ ' written after it. 
even to make the language more copious, but to wipe from Ireland and her inhabitants the character of being a savage nation and a barbarous people.

All of the differences between the text of the stanza in the R.I.A., 24 B 3 manuscript and that in Casey's prospectus for his Athanasia Hibernica are of such a minor orthographical nature as to have no great impact on the interpretation of the quatrain. They are, however, of considerable significance when we turn to consider one other, previously unnoticed witness to the transmission of this stanza into the modern period.

Since the publication of the studies of Michael Casey and his work by Sharpe and Nic Dhonnchadha in 2019, one further piece of evidence has come to light that, if it does not provide any more clues to the identity of the Colmán mac Oililla invoked in the poem discussed above, nonetheless does offer some more insight into the transmission of the penultimate quatrain of this composition into the nineteenth century. The source in question is a signboard of unidentified provenance, now kept in the collections of the Wellcome Library in London (reference no. 44690i; reproduced here as Figure 1). ${ }^{53}$

The top part of this signboard features an oil on wood painting, $55 \times 66.3 \mathrm{~cm}$ in dimension, that is described in the Wellcome Collection catalogue as depicting 'vases of flowers and a botanic garden with Saint Peter'. The identification of the painter as someone with the surname 'O'Brien' is indicated by the words $O$ 'Brien fecit in the lower right-hand corner of the image. The catalogue entry refers to this figure as 'O'Brien (Painter), active 1778', but offers no further information to substantiate the stated period of activity beyond a reference to a 2006 catalogue of British and Irish paintings in public collections, where it is merely observed that the O'Brien in question is 'presumed working $19^{\text {th }}$ century or earlier'. ${ }^{54}$ It can be established from other sources, however, that this painter may have been one Thomas O'Brien of Dublin, who exhibited a work described as 'Venus soliciting Vulcan to make armour for her son' at the 1778 exhibition of the Free Society of Artists in London. ${ }^{55} \mathrm{He}$ is probably identical with the 'Obrien Tommaso, Irlandese Pittore' noted in Florence, Archivio di Stato MS 154 as having been elected as a member of the Florentine Accademia del Disegno on 21 September $1798 .{ }^{56}$

Inscribed on the signboard immediately below the painting are six lines of text, four of which allow us to connect the signboard with some certainty to the nineteenth-century 'herb doctor' Michael Casey and the prospectus for his Athanasia Hibernica, and thus indirectly to Conla Mac an Leagha's early

${ }_{53}^{53}$ Permanent link: (https://wellcomecollection.org/works/me4wtyvb) (17 June 2021).

${ }^{54}$ Christopher Wright et al., British and Irish paintings in public collections (New Haven and London, 2006), p. 610.

55 Algernon Graves, The Society of Artists of Great Britain, 1760-1791. The Free Society of Artists 1761-1783. A complete dictionary of contributors and their work from the foundation of the societies to 1791 (London, 1907), p. 184.

${ }^{56}$ Michael Wynne, 'Members from Great Britain and Ireland of the Florentine Accademia del Disegno 1700-1855' in The Burlington Magazine, cxxxii, no. 1049 (1990), pp 535-8, at p. 537. 


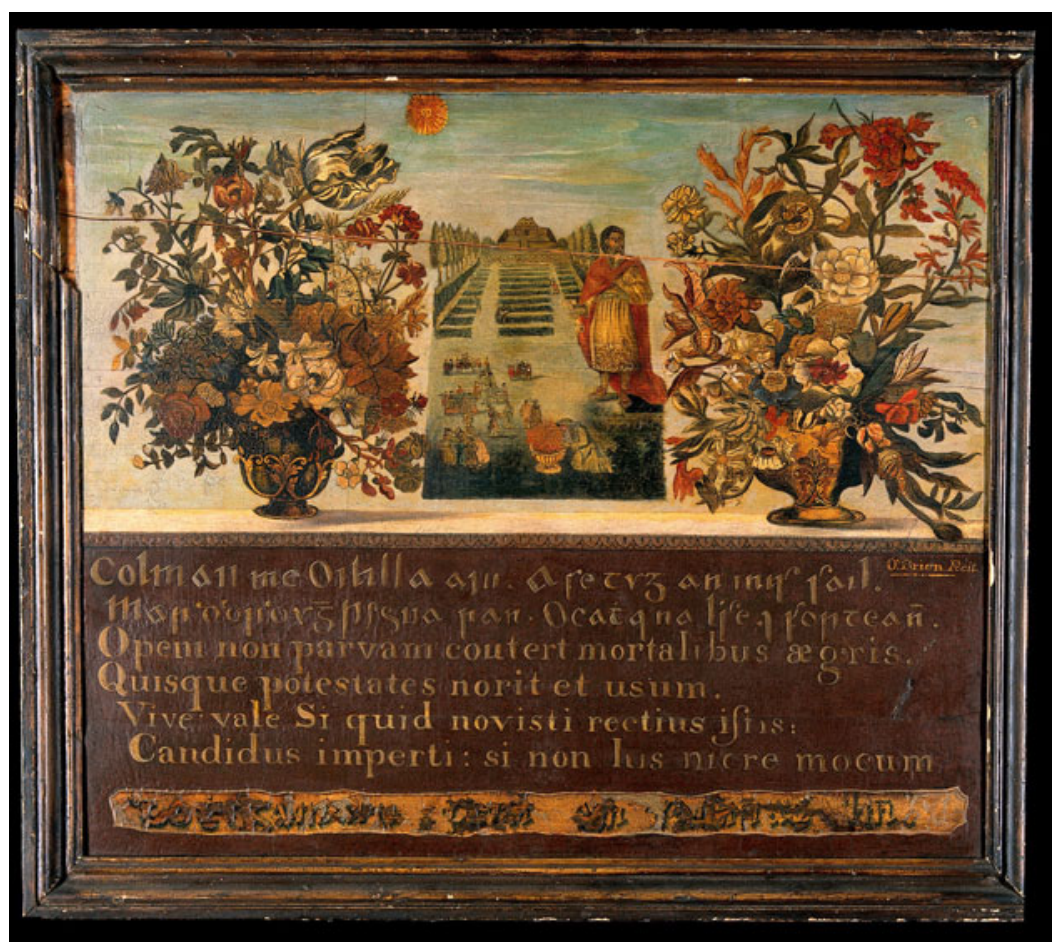

Figure 1. 'Vases of flowers and a botanic garden with Saint Peter. Oil painting by O'Brien'. Credit: Wellcome Collection (Public Domain)

sixteenth-century prosimetrical remedy book. The last two of the six lines have been identified in the Wellcome Collection catalogue entry for the artefact as 'a garbled version of (Latin hexameters drawn from) Horace, Epistles I.6.66-7', namely Vive vale. Si quid novisti rectius istis/Candidus imperti; si non, his utere mecum ('Live long, farewell. If you know something better than these precepts, pass it on, my good fellow. If not, join me in following these'). ${ }^{57}$ The two lines immediately preceding this quotation - the significance of which is discussed further below - are also in Latin and are likewise transcribed in the Wellcome Collection catalogue entry, albeit without any identification of a source.

By contrast, both the language and meaning of the first two of the six lines of text visible on the bottom half of the signboard had remained entirely unidentified until February 2020, when Julia Nurse, Research Development Specialist at the Wellcome Library, contacted the Department of Early Irish at Maynooth University with a request for help in translating what appeared to be a passage in Irish on an item in their collections that was of unknown provenance, but was

57 The passage is edited and translated by H. Rushton Fairclough in Horace: Satires. Epistles. The art of poetry, Loeb Classical Library 194 (Cambridge, MA, 1926), pp 290 91 (where the lines of the text are 67-8, and the reading si nil is given for the si non on the signboard). The final three words of the Latin text appear to have been corrupted on the sign. 
thought to be a herbalist's signboard. ${ }^{58}$ Upon examination of the passage, it immediately became clear that the first two lines of text on the signboard consisted of the same quatrain of verse invoking Colmán mac Oililla as that which occurs in Conla Mac an Leagha's prosimetrical remedy collection. The Wellcome Library catalogue entry for the item was subsequently updated to reflect this finding. ${ }^{59}$ Although the quatrain is also noted in the studies of Michael Casey's medical transcripts published by Sharpe and Nic Dhonnchadha, neither scholar makes any mention of its presence on the Wellcome Collection signboard, suggesting that they were unaware of the existence of this artefact; indeed, Sharpe stated explicitly that the stanza 'has not been found elsewhere'. 60

Close analysis of the orthographical features of the Irish quatrain as it appears on the signboard indicates that this version of the stanza bears closer comparison to that found in Casey's prospectus for the Athanasia Hibernica than it does to the text in the R.I.A., 24 B 3 manuscript witness. For example, the inscription on the signboard features vocalic elision in do orduigh, as is the case in Casey's rendering, and the words given as rand and forthend in the manuscript witness are written as a single ' $n$ ' with a suspension mark over it on both the signboard and in Casey's prospectus. ${ }^{61}$ The version of the text on the signboard also features what was probably intended to be the letter ' $b$ ' with a suprascript $\operatorname{dot}^{62}$ before the initial letter ' $f$ ' in the genitive plural form of the word fear '(of) men', the last two letters of which are themselves abbreviated on the signboard, perhaps in an effort to save space. ${ }^{63}$ A perceptible separation is also visible between the letters ' $a$ ' and 'se' at the beginning of the second line of the quatrain in both Casey's transcription and on the signboard, whereas in the manuscript witness these three letters are written continuously with no space between them. The introduction of a space in the two later witnesses of the text is significant to the extent that it obscures what is probably the correct syntax of the line, namely the copular construction $a s e^{\prime}$ 'it is he' (rather than a sé, which could be understood as the numeral 'six'). Similarly, the manuscript reading of the text immediately following this, namely aninís fail, is written in both Casey's prospectus and on the signboard with a clear space between an and Inis, suggesting that the first element may have been understood in the later sources as the Modern Irish form of the definite article, followed by Inis Fáil, a common poetic designation for Ireland in early texts. The use of an article before a place name of this kind would be unusual, however, and is indeed unparalleled in

58 Email comm., 11 Feb. 2020.

59 The updated catalogue entry was highlighted on the Wellcome Library Twitter account on 1 Mar. 2020 (https://twitter.com/WellcomeLibrary/status/1234095517073838081).

60 Sharpe, 'Michael Casey', p. 38.

61 The suspension mark over the ' $\mathrm{n}$ ' in the word given as $r a \bar{n}$ on the signboard is so faint that it is in fact difficult to determine whether it was ever there at all; however, it is clearly visible over the word forteañ.

${ }^{62}$ It in fact looks more like an ' 1 '; one wonders if this could be the mistake of a signmaker copying from a textual source, but unfamiliar with the language.

${ }^{63}$ The letter resembling a 'q' that follows the letters $f e$ - on the sign was probably intended to be the common manuscript abbreviation for the letters ar (thus giving the reading bfear exactly as it is found in Casey's prospectus for the Athanasia Hibernica); however, one would normally expect this abbreviation to feature a single stroke through the descender of the letter, and this is not visible on the sign. Here again, this could be interpreted as an error by a signmaker unfamiliar with Irish and/or the kind of abbreviations typically found in earlier Irish manuscripts. 
the examples of Inis Fáil given in $e D I L .{ }^{64}$ On this basis, it seems more probable that the earlier manuscript witness of the text was intended to be read as a nInis Fáil 'into Ireland', with the $a$ being a typical later spelling of the preposition $i$ meaning 'into', followed by an expected $n$ - to mark nasalisation on the initial vowel of the following word.

In addition to the orthographic similarities that can be established between the text of the Irish quatrain in Casey's prospectus and that on the Wellcome Collection signboard, there is further, even more compelling, evidence to suggest a link between these two sources. First is the fact that the signboard features two lines of Latin, sandwiched between the quatrain of Irish poetry and the quotation from Horace's Epistles noted above, that are transcribed in the catalogue entry for the artefact as Opem non parvam confert mortalibus aegris./Quisque potestates $<$ plantarum?> norit et usum ("whoever should recognise the powers and use [of plants?]/grants no small aid to sick men'). ${ }^{65}$ While the precise source of this quotation is unclear, it is surely of some significance that the very same lines of Latin, differing only in the spelling of norit as noret, are given at the conclusion of Casey's prospectus for the Athanasia Hibernica. There they are accompanied by the following lines in Irish, which, while not an exact translation of the Latin, nonetheless convey a similar sentiment:

Le moran tairbe air galaraib súg na lus

Is fior gur maiteas, a ccleactad don anbfan boctt.

With great benefit for ailments [is] the juice of herbs

It is true that it is a good thing, to use them for a poor helpless person.

The link suggested by this correspondence is strengthened by another, albeit more indirect, parallel between the text on the signboard and that of Casey's prospectus, namely the fact that Casey begins the latter with the following quotation from Horace's Ars poetica (again rendered into Irish verse immediately afterwards):

Ut silvæ foliis pronos mutantur in annos;

Prima cadunt: ita verborum vetus interat ætas,

Et juvenum in ritu florent modo nata; vigentque. - Hor.

As forests change their leaves with each year's decline, and the earliest drop off: so with words the old race dies, and, like the young of human kind, the new-born bloom and thrive. ${ }^{66}$

Admittedly, this is not the same quotation from Horace as that which appears on the signboard (the latter of which can, as demonstrated above, be identified as an excerpt from his Epistles), and Casey's purpose in citing this particular passage at the beginning of his prospectus was evidently to link the imagery of nature's

${ }_{64}^{64}$ For examples, see $e D I L$, s.v. 1 inis (http://www.dil.ie/28744) (7 May 2021).

${ }^{65}$ My translation.

${ }^{66}$ Cf. Fairclough (ed. and trans.), Horace: Satires. Epistles. The art of poetry, pp 454-5. In a letter to Maura Scannell dated 18 Feb. 1987 (now found in N.L.I., MS 50,654), Pádraig De Brún suggested that the opening and concluding excerpts of Irish verse in the prospectus might 'quite possibly be Casey's own (being translations of the preceding Latin in each case)'. 
cyclicity with the concept of the decline and subsequent renewal or preservation of the Irish language in which his medical manuscript sources were written. However, when considered in light of the aforementioned correspondences between the first four lines of text on the signboard and the two quotations in Casey's prospectus, it may nonetheless be of some significance that the same classical author has been cited in both contexts.

One last observation might be made regarding the text on the Wellcome Collection sign that, like the distinctive quatrain of Irish poetry given as the first two of the six lines of text on the lower half of the board, supports its association with an Irish milieu. This is the fact that what appears to be a seventh line of text is faintly visible at the bottom of the sign, set somewhat apart from the six lines (two in Irish, four in Latin) described above, and surrounded by a rectangle of unstained wood. Unfortunately, most of this line of text is now illegible, but it can nonetheless be argued that it is also in Irish: for the first two letters read fairly clearly as $d o$, followed by what is either the letter ' $\mathrm{t}$ ' or ' $\mathrm{g}$ ' with a dot over the top. This is probably the Irish preposition $d o$ ('to, for'), followed by a consonant with the diacritical mark of lenition that one would expect after that grammatical element. A second letter ' $g$ ' is also visible in the second word of the line, possibly giving a reading do thig ... ('to the house'?) followed by what may be the letters an (possibly the definite article 'the'?) However, little else is clearly visible besides what appears to be a word beginning with ' $p$ ' in the middle of the line, followed by what may again be the definite article an. The sense of the line as a whole is thus unclear, but one might wonder whether it contained either a reference to an individual or place, or perhaps part of a prayer.

Despite these remaining uncertainties, the evidence adduced above seems sufficient to establish a connection between this previously unidentified signboard in the Wellcome Library collections and the work of the nineteenth-century Irish 'herb doctor' Michael Casey. More specifically, the signboard can be linked to the prospectus for Casey's herbal, the Athanasia Hibernica, the first number of which was mentioned in the Dublin Freeman's Journal in 1825 as being at press, 'by subscription', with Thomas Courtney in Whitefriar Street. ${ }^{67}$ Might the signboard have been created as an advertisement for this herbal? The inclusion of a couplet of poetry on a sign publicising Casey's services is not unparalleled, if one considers the apparently well-known (but evidently distinct) signboard reported to have been visible outside Casey's domicile in Myler's Alley, Dublin, on which a verse couplet in Irish likewise featured. ${ }^{68}$ It has been suggested above that the artist responsible for producing the image of Saint Peter in botanical gardens on the upper half of the signboard may have been the Dublin painter Thomas O'Brien, who is known to have been active in London during the last quarter of the eighteenth century; if this identification is correct, it may provide a tentative link to explain how the signboard could have made its way into the Wellcome Collection in London. Unfortunately, however, answers to the questions of whether the sign might have

${ }^{67}$ Sharpe, 'Michael Casey', p. 20; the concluding paragraph on the verso of Casey's prospectus for the work states that potential subscribers 'may inspect the ancient work at Courtney's Printing Office, 18, Whitefriar-street, Dublin, by giving ten hours notice of his or their intention, name or names, place or places of abode: and if convenient, (the more agreeable) to be accompanied by a person versed in the Irish or Scotch Gaelic'.

${ }^{68}$ As noted above and by Sharpe, 'Michael Casey', p. 2. 
originally been displayed in Dublin by Michael Casey himself, or of precisely where it might have been located, remain elusive.

\section{VI}

The didactic medical poem published in full above, although attested only in a single manuscript witness of the early sixteenth century and representing only a tiny fraction of the medical verse preserved in that source, is significant in that it simultaneously offers us a glimpse in two temporal directions: one backwards to the medical tradition and learned authorities of early medieval Ireland, and another forwards to the intriguing life of an antiquarian and 'irregular practitioner' of medicine working in early nineteenth-century Dublin. These two opposing chronological dimensions of the composition are connected, however, insofar as it seems to have been the poem's very appeal to ancient Irish authority in particular that prompted the 'Doctor \& Botinist' and 'Manascript scollar' Michael Casey to include the penultimate stanza of the work in the prospectus for his Athanasia Hibernica. Casey evidently thought that it provided an apt illustration of the antiquity of Irish medical learning and, therefore, of the value of the premodern Irish medical manuscripts as a source for the herbal remedies of which he professed to have useful (and perhaps lucrative) knowledge.

To what extent Casey was aware of the classically-rooted learned background to many of the cures in the manuscript sources on which he drew is not altogether clear, and one can hardly ignore Sharpe's observation that 'In Casey's mind [...] a nationalist Providence had provided the Irish nation with simple medicines to heal all manner of ailments. He always chose not to recognize the plain fact that his old Irish medical treatises were translated from Latin works composed on the Continent, preferring to promote them as native remedies. ${ }^{69}$ Notwithstanding, Casey's citation of a stanza from an Irish-language medical poem in the prospectus for his herbal, and the clear connection of these lines with the text inscribed on the previously unprovenanced signboard now kept in the Wellcome Collection in London, shed intriguing light on the relationship that obtained between manuscript, print and material culture in Ireland over a period of several centuries, as well as on the appreciation shown by at least one nineteenth-century scholar for the contents of the premodern Irish medical manuscripts. ${ }^{70}$

${ }^{69}$ Sharpe, 'Michael Casey', p. 33.

70 The research for this article has been facilitated by a Laureate Award from the Irish Research Council for the project Medieval Irish medicine in its North-western European context: a case study of two unpublished texts (MIMNEC, grant agreement no. IRCLA/ 2017/57). The findings reported here are based in part on work first presented at the 2016 Tionól of the School of Celtic Studies, Dublin Institute for Advanced Studies, and at a workshop on 'Science and Medicine in the Insular Middle Ages' held at Queen's University Belfast in December 2018. I am grateful to Dr Sarah Baccianti for the invitation to present at the latter gathering, to the audiences of both events for their input, and to the anonymous reviewers of this journal for their comments on the written version. 